\title{
ATMOSPHERIC DIMENSIONS OF ARCHITECTURE
}

\author{
A B S S T R A C
}

This paper proposes four methodological tools for investigating architectural atmospheres: objective experience, holistic measure, computational simulation and atmospheric visualization. These tools have emerged from a broader $\mathrm{PhD}$ research agenda based on the hypothesis that ephemeral effects of light, heat, sound, odor, carried on or in the air, present a scientific basis for precise construction of atmospheres in architecture. By describing my own atmospheric methodology over a series of individual case studies, I will argue that architectural atmospheres can be scientifically investigated and precisely constructed, and that atmospheric approach to architectural research and design offers new invaluable knowledge about the invisible aerial behaviors that determine basic human experience of space. 


\section{INTRODUCTION}

By assigning the word dimension to an ephemeral notion such as atmosphere, I would like to imply two key ideas behind the research that I will present in this paper. First, atmospheric dimension refers to the experiential quality of architecture, its capability to trigger the senses and evoke moods, thus constructing a scenic background to our daily lives. Architects, intentionally or not, condition the air within buildings, set parameters and initiate invisible behaviors that are experienced by living beings as a characteristic atmosphere of a space. Our body registers and reacts to the ephemeral effects of light, sound, heat and odor, that are carried on or in the air, even before we consciously grasp the building as a whole. Indisputably, atmosphere is a significant and an inevitable product of the architectural design process, and therefore should be considered and discussed along with other, more commonly accepted features of built architecture, such as energy efficiency, affordability, or materiality. However, atmospheres are usually very difficult to precisely investigate or define, due to their elusive nature, subjectivity of spatial experience and the complexity of the physical processes that constitute them. In relation to this, atmospheric dimension also raises the question of measuring atmospheres, and focuses our research on those aspects of atmospheres that can be scientifically investigated, measured, explained and constructed. This paper will present methodological tools for investigating atmospheres that have emerged from a broader $\mathrm{PhD}$ research agenda based on the hypothesis that invisible aerial processes are potentially a scientific basis for precise construction of architectural atmospheres.

The phenomenon of atmospheres can be discussed from a variety of distinctive perspectives. It is determined by a physical behavior within space that can be objectively analyzed and even intentionally constructed. At the same time it denotes subjective experience, mood and individual feelings that one cannot simply measure, and that raise social and political questions over their potential manipulative character. ${ }^{1}$ Atmosphere is at once a condition, and is itself conditioned ${ }^{2}-$ as it emerges from a series of interconnected spatial effects, and at the same time it $i s$ the effect itself. In the 1998 issue of the Berlin architectural journal Daidalos dedicated to the construction of atmospheres, Mark Wigley questions the very idea of constructing atmospheres, by stating that "those who embrace effect cannot approach atmosphere directly". ${ }^{3}$ He further writes that atmosphere "lacks definition" and "escapes analysis". He states that even though it is at the center of architecture, atmosphere cannot simply be addressed nor controlled. Whereas I would agree on the importance of atmosphere for architectural design, I intend to challenge the idea of it being indeterminate and impossible 
to analyze. It is precisely because of its importance that it should be the subject of scientific investigation conducted by architects. Therefore, I will discuss four methodological tools for investigating and constructing atmospheres: (1) objective experience, (2) holistic measure, (3) computational simulation and (4) atmospheric visualization. These tools have been crucial for my ongoing $\mathrm{PhD}$ research on the science of architectural atmospheres, and have simultaneously emerged from a variety of different investigative approaches over a series of individual case studies. I will further illustrate the proposed methodology with four examples: (1) in-situ case study of a constructed atmosphere within a residential building in Belgrade, (2) computational analysis of aerial processes in a 16th century hammam, (3) atmospheric visualization of a conceptual building in different weather conditions and (4) construction of atmospheres during the conceptual design process for a Cultural Center in Afghanistan. Additionally, this paper seeks to make a broader methodological contribution to the study of atmospheres by highlighting the importance of simultaneous investigation of existing everyday life atmospheres as given conditions, as well as the possibilities for their precise construction during the design process. I will argue that architectural atmospheres can be scientifically investigated and precisely constructed, and that atmospheric approach to architectural research and design offers new invaluable knowledge about the invisible aerial behaviors that determine basic human experience of space.

\section{OBJECTIVE EXPERIENCE}

Architectural atmosphere is directly related to immediate experience of space. It cannot be exclusively studied in an artificially created experimental situation, but needs to be experienced in the field, as a part of a complex environmental and social setting. We might say that it emerges from the interaction of tangible structure and invisible processes in the air, such as airflow, heat transfer or sound propagation, and is additionally conditioned by everyday life - or the uncertainty of natural and social events. This swirling climate of micro behaviors and macro events is experienced by human body and mind in a subjective and unique way. Atmosphere seems to evaporate with the subjectivity of its experience, and as such it is usually perceived as a mysterious metaphysical force that architects infuse into their projects, only meant to be experienced, and impossible to analyze or define. However, if atmosphere is fully manifested only when experienced, it would indicate that it can also be analyzed via immediate experience. In other words, human body can potentially be taught to recognize invisible spatial behaviors and to be able to objectively analyze and map atmospheres. This methodology is 
closely related to Henry Lefebvre's theory of rhythmanalysis, and his thoughts about the human body as an instrument to capture and analyze rhythms of its immediate surroundings. ${ }^{4}$ Lefebvre writes that in order to objectively analyze rhythm, one must be able to situate oneself simultaneously inside and outside of it..$^{5}$ It is necessary to be grasped by the rhythm, but at the same time to be able to distance oneself from it, in other words - to objectify ones subjective impressions of the phenomena in question.

Our in-situ case study of constructed atmospheres within the entrance spaces of a residential building "Odeon" in Belgrade was largely directed by immediate spatial experience gathered during a number of carefully planned and conducted field visits over a time span of three months (November and December 2015, January 2016). ${ }^{6}$ We noticed that objective analysis of immediate experience in the field gradually helps the researcher to start recognizing patterns of spatial behavior and to understand the logic of their occurrence. He (or she) develops a conscious sensitivity to atmospheric qualities of encountered spaces - subtle differences in light intensity, temperature variations or airflow directions. In time, the researcher becomes able to analytically disentangle the interconnected physical processes and to associate their effects to the features of built architecture. To simply illustrate, patterns of airflow are connected to the composition of openings in an enclosed space, sound reverberation is related to the position of objects in space and the structure of surface materials, light intensity depends on the depth and height of space and the distance from light sources etc. With every new field visit, novel atmospheric knowledge strengthens the abilities of the researcher to recognize certain effects within a highly complex environment. This type of careful analytical approach would in turn enable architects to precisely and consciously construct atmospheres in their own architectural practice, and it would potentially ensure the existence and rich variety of atmospheres in the future of built architecture.

\section{HOLISTIC MEASURE}

Immediate experience of atmosphere results with series of observations that in order to be scientifically valid need to be substantiated with objectively gathered data. For our field case study, this implied measurement of individual atmospheric parameters with highly accurate equipment, as well as detailed computational simulations that I will discuss further on in this paper. ${ }^{7}$ The idea of measuring architectural atmosphere results from the need for objective definition of the condition and flow of matter and energy in space, in order to understand and explain subjectively observed phenomena. ${ }^{8}$ By measuring the 
intensity of light, sound, temperature or humidity, we gain concrete values that quantify each fragment of space at a given moment. However, physical processes that constitute atmospheres are dynamic - the values measured at one point fluctuate in space and in time, and are affected by weather conditions, social activities, and other types of energies in the surrounding environment. Each collected value speaks little about the space as a whole, unless it is combined with other types of gathered information. It could be argued that traditional quantitative measure of individual parameters that determine architectural atmosphere is insufficient for its holistic understanding. This is why we introduce rhythm, as defined by Lefebvre, as a holistic type of measure, one that would be able to take into account the interconnectedness of atmospheric parameters in space and their constant variations in time. In other words, quantitative aspects of rhythm refer to concrete values within points in space and moments in time, whereas qualitative aspects connect those values they capture the logic of observed behaviors and measured parameters. ${ }^{9}$

To illustrate, an abundance of data that resulted from our in-depth field study of atmosphere was classified and analyzed following Lefebvre's differentiation of rhythms as cyclical or linear. ${ }^{10}$ In our case, cyclical rhythms refer to the susceptibility of atmosphere to the influences of natural reoccurring processes such as cycles of day and night, seasons, weather conditions etc. On the other hand, linear rhythms denote linear movement of a person in space, or successive changes of individual experiences in short intervals of time. ${ }^{11}$ Atmosphere potentially occurs at the intersection of cyclical and linear rhythms of space, and as a result of their synchronization. This might also mean that disharmony between these two types of rhythms would cause

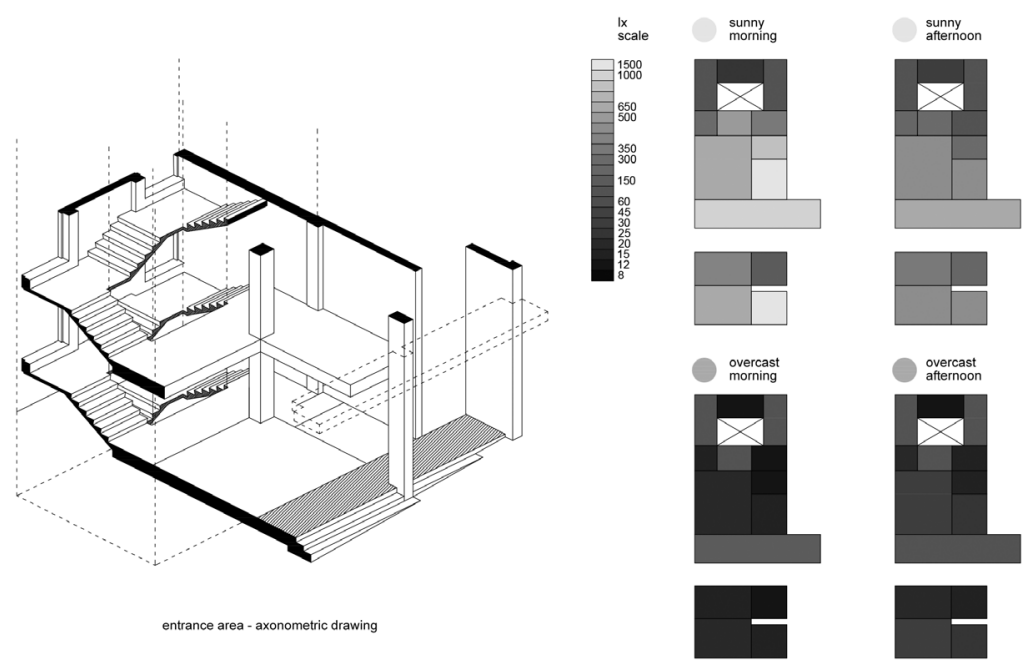

Figure 1. Daylight rhythms - drawn diagram, "Odeon” residential building, Belgrade, Serbia 
discrepancies and irregularities in the experience of space. Therefore, we may argue that correct rhythmical composition of architectural space based on a carefully developed sequence of events and experiences is fundamental for precise construction of atmospheres in architecture. Series of spatial rhythms observed in our field study clearly pointed to characteristic atmospheric zoning of investigated spaces, as shown on the diagrams in Figure 1. Also, we identified several reoccurring atmospheric patterns, in relation to time of day and weather conditions. These key states of atmosphere shift and repeat in cycles, whereas each specific state offers a characteristic linear succession of conditions within space that determine potential experiences and events.

\section{COMPUTATIONAL SIMULATION}

The science of architectural atmospheres lies in the interconnectedness of all the individual physical processes in space and in time. For example, a single disturbance in air currents initiates multiple changes in the environment, possibly of much larger scale and effect. However, atmospheric processes are experienced, observed and measured by researchers in fragments, rather than as holistic phenomena. Human mind is not equipped to handle large amounts of data, nor to instantly visualize and understand any complex behavior. We interpret fragmented observations, measure individual parameters to confirm or deny such observations, and gradually build an idea or a hypothesis of the investigated environment as a whole. This idea can further be tested and developed via a series of computerized simulations of climatic processes within the investigated space. In other words, three dimensional computer model of the building is tested in a simplified experimental setting involving key features of real physical context, such as average meteorological conditions and applied
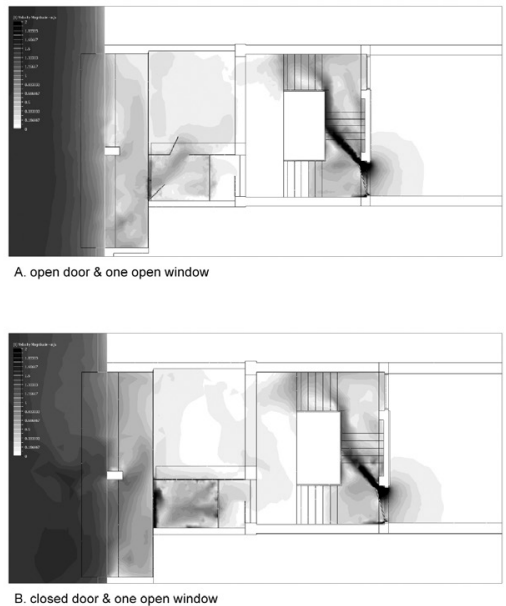
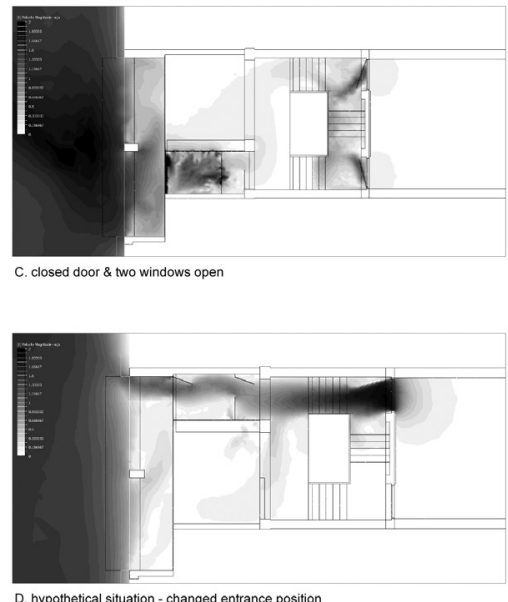
materials. This in turn informs the research process by directing attention to areas of interest that would possibly be overlooked by immediate observations or individual measuring. Advanced software packages, such as Computational Fluid Dynamics (CFD) developed by Autodesk, take into account all types of available data - airflow direction \& velocity, pressure levels, air temperature, etc. - within one comprehensive environmental simulation. These simulations connect fragmented data and generate complete atmospheric images of investigated spaces. In our field study, computational simulations of airflow have shown characteristically well-designed ventilation of the entrance space, as shown in Figure 2 (A,B,C). Air openings have been positioned in such a way that they introduce and direct air well into the secluded spaces (that would otherwise remain non-ventilated), whereas characteristic spatial configuration lowers the air velocity of the incoming air currents where needed. These conclusions have further been confirmed by direct measurement on site.

Another important contribution of computational simulations to atmospheric methodology is the possibility to investigate hypothetical situations, as well as historic buildings that have either been demolished or are difficult to visit. Figure 2 (D) shows airflow simulations of original spaces adjusted in a few carefully chosen ways to test existing ventilation strategies (changing the position of openings, or excluding some key air shafts). These have clearly shown that the airflow patterns would be significantly changed, and that air velocities would either be too high or too low to satisfy basic human comfort conditions. When historic buildings are concerned, environmental aspects have been mostly neglected by written histories of architecture, probably due to their invisibility - they were impossible to substantially document with available

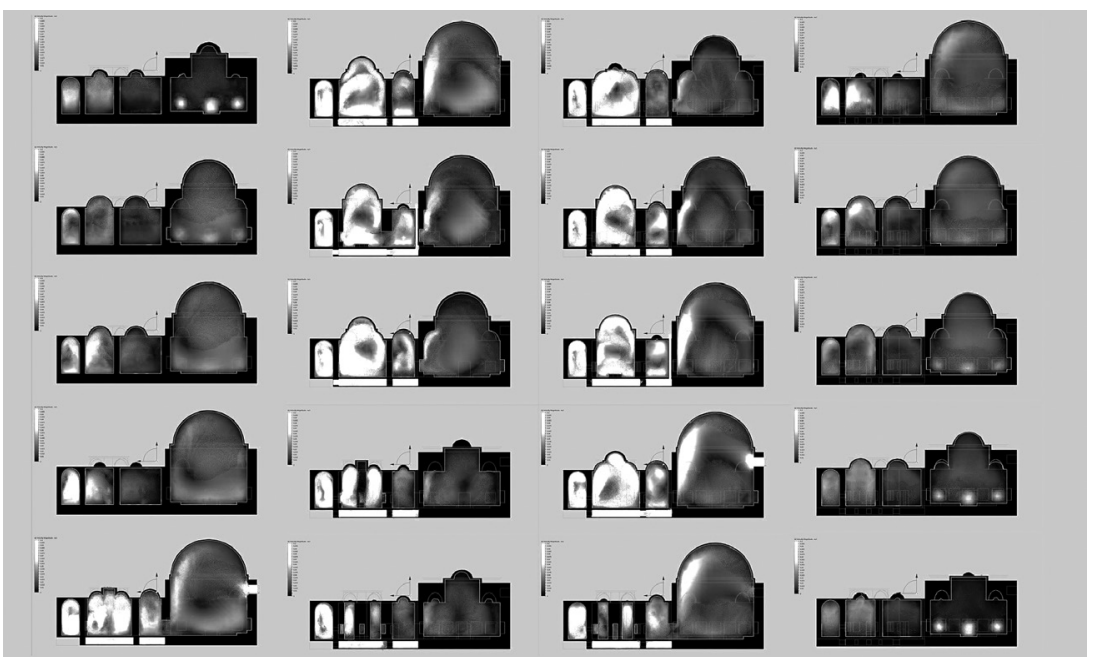

Figure 3. Airflow and heat transfer - computational simulation, Islamic Hammam, Luleburgasz, Turkey 
architectural media. ${ }^{12}$ Given the research possibilities of contemporary digital tools, we conducted a case study of a traditional 16th century Islamic hammam in Luleburgasz, designed by famous Ottoman architect Mimar Sinan. ${ }^{13}$ Detailed computational simulations resulted with a specter of unraveled aerial patterns that spoke about the intricate relationship between the well known architectural features of Islamic baths - the spherical roof, hypocaust system bellow the floors and the characteristic division of space into differently sized bathing chambers - and their elusive and historically undocumented atmosphere. Figure 3 shows behavioral rhythms of the bath in two-dimensional fragments, revealing climatic zoning throughout the space, from colder and more spacious undressing chambers on the right, to the well heated bathing rooms above the hypocaust void on the left, as well as much more subtle variations within single chambers, impossible to presume or even completely register via direct experience.

In addition to investigating constructed atmospheres, the research presented here also speculates on the possibility of precise construction of atmospheres during the early stages of architectural design process. Gathered atmospheric knowledge can be employed in traditional design process to advance the level of architectural thinking to atmospheric aspects of future spaces. In addition to this, computational simulations present an invaluable tool for testing atmospheric behaviors of conceptual projects. Figure 4 shows our conceptual design for a Cultural Center in Bamiyan Valley, Afghanistan, where we developed a multiple courtyard system as an atmospheric mechanism that modulates the existing air flows to construct specific atmospheric conditions inside. ${ }^{14}$ The design and research process consisted of five major steps. Firstly,

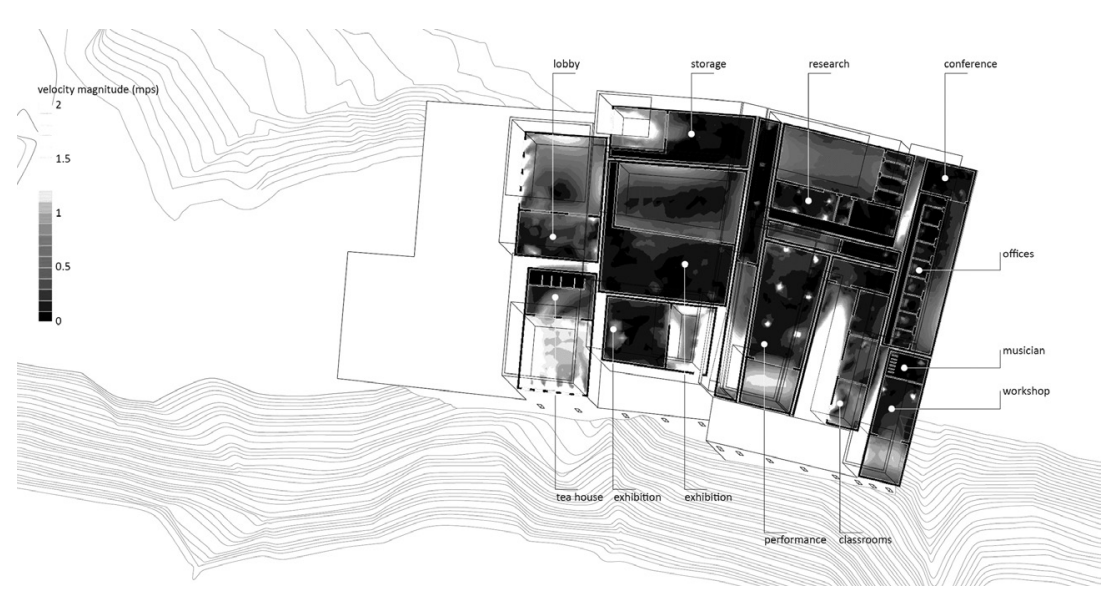


we investigated traditional courtyard house configuration, its abilities to capture the incoming air and to direct it towards the interior space, as well as the connection between varying courtyard properties and attained airflow patterns and velocities inside. Obtained results were then employed to construct a multiple courtyard system that would adapt the inner atmospheric conditions to the desired cultural program (exhibition spaces, classrooms, lecture hall etc). After several problematic stagnant air zones were marked in second phase of simulations we decided to introduce underground air channels, that would additionally capture the air from the incoming winds and direct it towards the courtyards. This was further confirmed by one final phase of CFD simulations, now including the impact of underground air channels on the overall design. As a result of this approach, discussions about spatial experience were introduced in early design stages, and atmosphere became an intricate and invaluable part of the conceptual design, opening vast possibilities for its detailed development in the following stages of the project.

\section{ATMOSPHERIC VISUALIZATION}

Atmospheric visualization is related to previously explained computational simulation, but is here described separately due to its different application in architectural practice, as well as different methodological possibilities it offers. Both are based on precise computational analysis of an abundance of environmental conditions. Computational simulations are being excessively used in detailed design for a variety of important analyses of building's performance (such as structural stability, daylight or ventilation analyses etc.), but rarely are these employed in investigating conceptual atmospheres, since images (or diagrams) that these software packages produce are not intuitive enough for architects to instantly grasp them (see Figures 2-4). On the other hand, architectural visualization tools, such as 3dsMax and V-Ray, rely on traditional architectural media - photography - to communicate with architects, and herein lies their invaluable potential for atmospheric research. Architectural visualization is mainly being used in contemporary practice for representational purposes, that is to show the client how the building would look like before he spends the money to build it. However, once it is employed during the conceptual or detailed design process for generating data from a variety of different atmospheric scenarios that inform the process and direct design decisions, these tools shift from mere representation of form to complex simulation of space - what we will here, for purposes of clear distinction, address as atmospheric visualization..$^{15}$ 


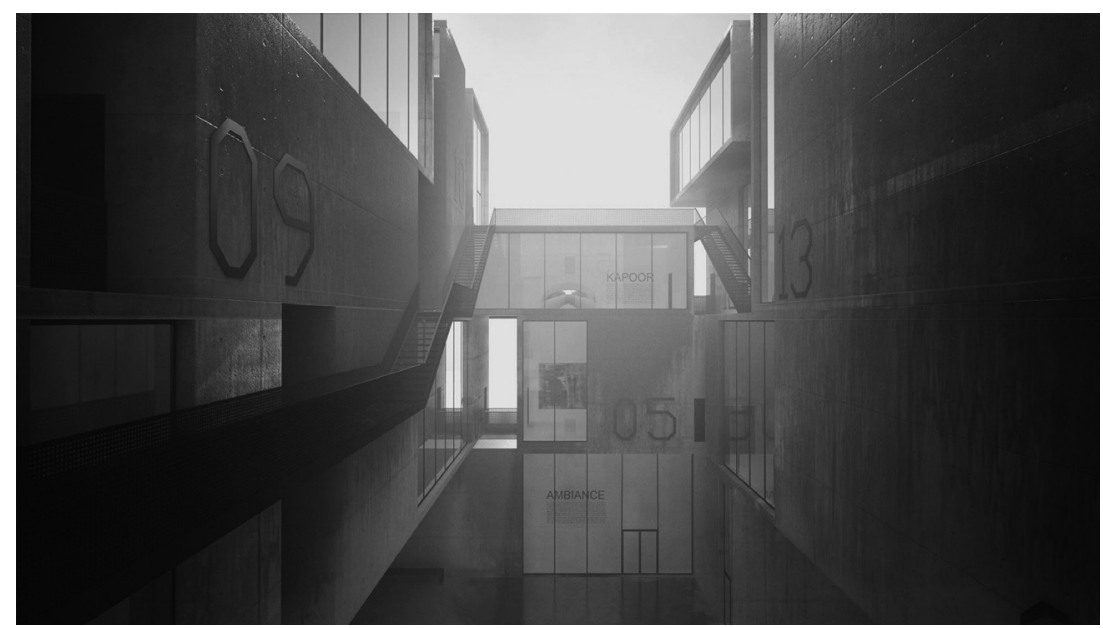

Figure 5 a . Hazy dawn - atmospheric visualization, Museum 16|25, conceptual project

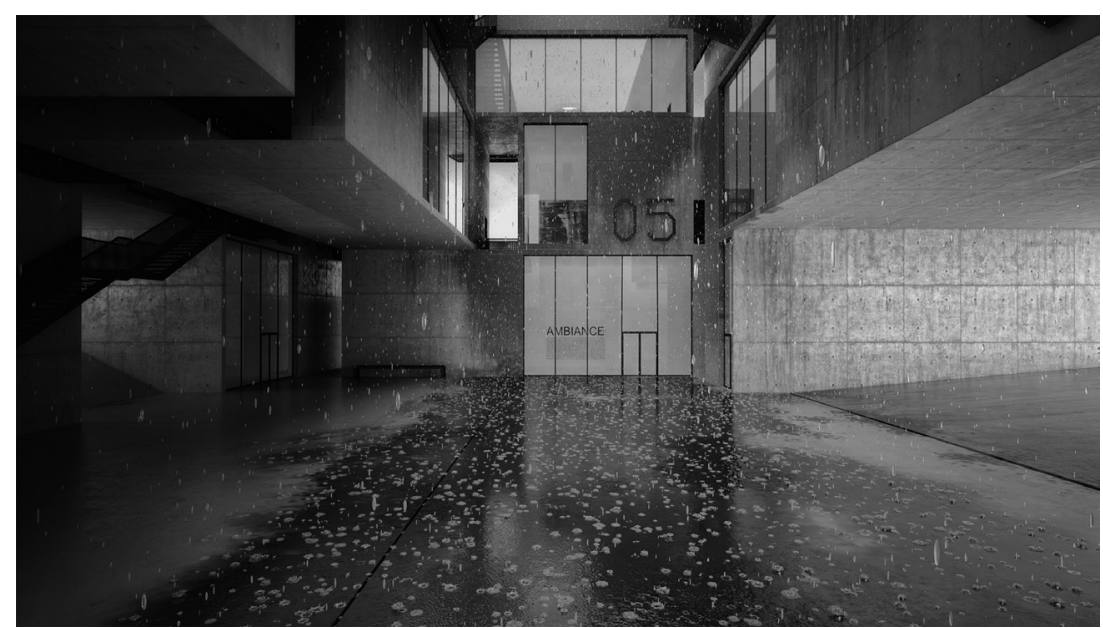

Figure 5b. Rainy afternoon-atmospheric visualization, Museum 16|25, conceptual project 
Atmospheric visualization tools are based on the logic of real life phenomena, and are capable to precisely simulate any hypothetical real life situation, by simultaneously calculating various physical processes (lighting, material behavior or weather conditions) as part of a single atmospheric scenario. This means that each environmental condition can be precisely controlled in order to tune the overall atmospheric effect of a building (Figures 5a, 5b). Manual tuning of the scene geometry, materials, environment settings and rendering parameters, brings one closer to understanding the connections between spatial configuration, material behavior and environmental conditions, thus obtaining invaluable tacit knowledge and developing one's own 'atmospheric intuition', similar to the capabilities developed while doing atmospheric research in the field. In this process visual images become mediators for communicating obtained data, and for transforming the invisible spatial behaviors to visible information for architects to react upon and further develop. ${ }^{16}$ That being said, I would argue that atmospheric visualization is an invaluable methodological tool for the science of architectural atmospheres and for architectural practice in general, as it connects all distinctive fragments of atmospheric knowledge, gathered by immediate experience, measurement, or via computational simulations, into one holistic virtual setting for constructing future atmospheres.

\section{CONCLUSIVE REFLECTIONS - FIELD MAPPING}

Atmospheric research asks for constant change of perspective, of going forward and backward, from being a distant observer to experiencing the space first-handedly, and letting oneself be grasped by its atmosphere. Four methodological tools discussed in this paper have the potential to position the researcher in this specific way, ensuring the objectivity of the obtained results, as well as the experiential depth of the performed study. Simultaneous application of these tools and the interweaving of gathered information are key features of the proposed methodology. Objective experiences, holistic measures, computational simulations and atmospheric visualizations all collect and generate data, but eventually, it is the researcher who needs to connect all the various types of information and to form a complete mental image of the investigated atmosphere. The whole process resembles field mapping (field here signifies action of matter through the presence of an intervening medium of air), where each gathered input speaks about the field, and all of the inputs are intricately connected and perfectly coherent. Atmospheric methodology ideally leads to recognizing and mapping behavioral patterns and regularities, gradients of intensities and subtle differentiations within heterogeneous spaces. Once key field conditions are established and defined in relation to 
the investigated space, the areas in-between can be mapped accordingly, as a superposition of identified atmospheric patterns. Atmospheric methodology brings architects closer to their own projects - as architects gradually develop a unique sensitivity to the ephemeral environment, atmosphere become a carrier of this new type of scientific knowledge about the life of architectural spaces. Invisible spatial processes, carried on or in the air, are assigned concrete qualities and rules of behavior, which in turn has the potential to significantly improve, if not even completely transform the traditional design process in the future. Re-Envisioning Research, ed. Phillip Vannini (London: Routledge, 2015), 34-35.

Mark Wigley, "The Architecture of Atmosphere," Constructing Atmospheres, Daidalos, no. 68 (1998): 27. 
Ibid, 27.

This research was conducted for purposes of the paper Rhythmanalysis of architectural atmosphere: Air and light of two entrance areas of the building "Odeon" written for the course Science of Space, as part of $\mathrm{PhD}$ studies at University of Belgrade - Faculty of Architecture, Professor Dr Ljiljana Blagojević.

For conducting measurement in the field we used following equipment: Trotec TA300 thermoanemometer (measurement range 0.1-25 mps, resolution $0.01 \mathrm{~m} / \mathrm{s}$ ), Trotec BF05 luxmeter (measurement range 0-40.0001x, resolution 0.111x), FlirOne thermal imaging camera (temperature range $-20^{\circ} \mathrm{C}-120^{\circ} \mathrm{C}$, precision $0.1{ }^{\circ} \mathrm{C}$, resolution $160 \mathrm{x} 120 \mathrm{px}$ )

Branislav Milenković defines dimension as a need to define position and basic flow of objects in space. See: Branislav Milenković, Uvod u arhitektonsku analizu I (Beograd: Građevinska knjiga, 2001), 41.

Lefebvre, Rhythmanalysis, 8-9.

Ibid, 8-9;

Milenković writes about multispaces, for which every new position in space initiates new experiences. See: Milenković, Uvod, 9.

Reyner Banham, The architecture of the well-tempered environment (Chicago: The University of Chicago Press, 1984), 12.

This research is explained in detail in: Anđela Karabašević, "The Matter of Void: From Absolute Space to Dynamic Flows." in What's the Matter? Materiality and Materialism at the Age of Computation, ed. Maria Voyatzaki (Barcelona: ENHSA, 2014), 895-908.

This research is explained in detail in: Anđela Karabašević and Vladislav Sudžum, "Poetics of Airflow in Architectural Design: The Case of Bamiyan Cultural Center Proposal," in Architecture in (R)evolution: PLEA 2015 conference proceedings (Bologna: PLEA, 2015);

Linda Groat and David Wang clearly define the difference between representation and simulation in architectural research. Whereas representation is a fixed image that stands for a real object and has qualities that describe and depict the real thing (such as architectural drawings or photographs), simulation is taking place only when data from various scenario inputs can be generated from representations. See: Lynda N. Groat and David Wang, Architectural Research Methods (Hoboken, New Jersey: John Wiley \& Sons, 2013), 356-357.

For more detailed discussion on atmospheric visualization see: Anđela Karabašević, "Architectural Atmosphere in the Age of Computational Simulations: The Case of Pre-Constructed Space," in Going Digital: Innovations in Contemporary Life: conference proceedings (Belgrade: STRAND, 2015), 113-124. Anđela Karabašević, "Computational Atmospherics as a Design Tool," in Conference Proceeding: The 3rd International Conference S.ARCH 2016 (Erlangen: Get it Published, 2016), 271-279. 
Anderson, Ben, and James Ash. “Atmospheric Methods.” In Non-Representational Methodologies: Re-Envisioning Research, edited by Phillip Vannini, 34-51. London: Routledge, 2015.

Anderson, Ben. “Affective Atmospheres.” Emotion, Space and Society, Vol. 2, No. 2 (2009): $77-$ 81.

Banham, Reyner. The architecture of the well-tempered environment. Chicago: The University of Chicago Press, 1984.

Borch, Christian, ed. Architectural Atmospheres: On the Experience and Politics of Architecture. Basel: Birkhäuser, 2014.

Connor, Steven. "Thermotaxis." (2005). http://www.stevenconnor.com/thermotaxis/

Connor, Steven. "Building Breathing Space.” (2004). http://www.stevenconnor.com/bbs/

Griffero, Tonino. Atmospheres: Aesthetics of Emotional Spaces. Farnham: Ashgate Publishing Ltd., 2010.

Groat, Lynda N. and David Wang. Architectural Research Methods. Hoboken, New Jersey: John Wiley \& Sons, 2013.

Heschong, Lisa. Thermal Delight in Architecture. Cambridge: The MIT Press, 1979.

Karabašević, Anđela. "The Matter of Void: From Absolute Space to Dynamic Flows." In What's the Matter? Materiality and Materialism at the Age of Computation, edited by Maria Voyatzaki, 895-908. Barcelona: ENHSA, 2014.

Karabašević, Anđela, and Vladislav Sudžum. "Poetics of Airflow in Architectural Design: The Case of Bamiyan Cultural Center Proposal." In Architecture in (R)evolution: PLEA 2015 conference proceedings, unpaginated. Bologna: PLEA, 2015.

Karabašević, Anđela. "Architectural Atmosphere in the Age of Computational Simulations: The Case of Pre-Constructed Space." In Going Digital: Innovations in Contemporary Life: conference proceedings, 113-124. Belgrade: STRAND, 2015.

Karabašević, Anđela. "Computational Atmospherics as a Design Tool." In Conference Proceeding: The 3rd International Conference S.ARCH 2016, 271-279. Erlangen: Get it Published, 2016.

Lally, Sean, and Jessica Young, eds. Softspace: From a Representation of Form to a Simulation of Space, New York: Routledge, 2007.

Lefebvre, Henri. Rhythmanalysis. Space, Time and Everyday Life, Stuart Elden, Gerald Moore trans. New York: Continuum, 2004.

Milenković, Branislav. Uvod u arhitektonsku analizu I. Beograd: Građevinska knjiga, 2001.

Wigley, Mark. "The Architecture of Atmosphere." Constructing Atmospheres, Daidalos, no. 68 (1998): 18-27. 


\section{ATMOSFERSKE DIMENZIJE ARHITEKTURE}

\section{Anđela Karabašević}

U ovom radu predlažem četiri metodološka alata za naučno istraživanje arhitektonske atmosfere: objektivno iskustvo, holistička mera, kompjuterska simulacija i atmosferska vizualizacija. Ovi alati su proistekli iz šireg istraživačkog opsega zasnovanog na hipotezi da efemerni efekti - svetlosti, toplote, zvuka, mirisa - koji se manifestuju u vazduhu ili kroz vazduh, predstavljaju naučnu osnovu za precizno konstruisanje atmosfere u arhitekturi. Opisivanjem sopstvene istraživačke metodologije na primerima individualnih studija slučaja, braniću stav da se arhitektonska atmosfera može naučno istražiti i tačno konstruisati, i da atmosferski pristup arhitektonskom istraživanju i projektovanju nudi novo neprocenjivo saznanje o nevidljivim vazdušnim procesima koji određuju čovekov osnovni doživljaj prostora.

KLJUČNE REČI: ARHITEKTONSKA ATMOSFERA, ATMOSFERSKA METODOLOGIJA, OBJEKTIVNO ISKUSTVO,

HOLISTIČKA MERA, KOMPJUTERSKA SIMULACIJA, ATMOSFERSKA VIZUALIZACIJA

\section{KOSMOPOLITSKI PRIRUČNIK ZA DEKOLONIJALIZOVANU AFRIKU - TROPSKA ARHITEKTURA U SUVIM I VLAŽNIM ZONAMA PREMA FRIJU I DRUOVOJ \\ Jacopo Galli}

Edvin Maksvel Fri (Edwin Maxwell Fry) i Džejn Dru (Jane Drew), iako su poznati po svojoj ulozi u izgradnji Čandigara zajedno sa Le Korbizjeom, njihovom indijanskom iskustvu prethodila je duga karijera u Zapadnoj Africi koja je započeta tokom Drugog svetskog rata i trajala je do kraja 50-ih godina. Fri i Druova bili su aktivni u Gani i Nigeriji u izgradnji velikog broja objekata: škola, univerziteta, kuća, sela, poslovnih zgrada i muzeja. Njihovo iskustvo na terenu pretočeno je u knjigu Tropska arhitektura u suvim i vlažnim zonama (Tropical Architecture in the Dry and Humid Zones) konačno objavljenu 1964. godine. Ovaj rad ima za cilj da analizira njihovo uputstvo kao pokušaj da se uspostavi kosmopolitski i savremeni sistem za projektovanje specifičan za tropske predele. Eksperimentalni i naučni pristup koji je klimatskim podacima pronašao alat za stvaranje nove zasnovanosti moderne arhitekture ne oslanja se na analizu kulture ili reinterpretaciju vernakularnog, već na složenu analizu lokalnih uslova kako bi se došlo do odgovarajužih projektantskih rešenja. Tropska arhitektura u suvim $i$ vlažnim zonama predstavlja manifest regionalnog modernizma, dva naizgled suprotna koncepta koja su pomirena u projektantskom pristupu kojim se pokušava izgraditi nova kosmopolitska modernost.

KLJUČNE REČI: FRI\&DRU, TROPSKA ARHITEKTURA, GANA, NIGERIJA, AFRIKA, KLIMATSKI ZASNOVANO

PROJEKTOVANJE, KOSMOPOLITIZAM

\section{OD KINETIZMA DO KINETIČKE ARHISKULPTURE Nikola Marković}

Ovaj tekst predstavlja kratak esej o razvoju i nastanku kinetičkih arhiskulptura uz osvrt na istorijat refleksija umetničke prakse i razvoja kinetizma kroz umetnost i arhitekturu (u periodu od XVIII veka do danas). Poseban akcenat dat je sagledavanju kinetičkih pojavnosti arhiskulptoralnih objekata kao sve prisutnijih pojava inovativnog jezika savremene arhitekture sa kraja prošlog i početka ovog veka. Rad takođe ukazuje i na dug istorijski put od najranijih iskustava pokreta u umetnosti do sadašnjeg proučavanja vrednosti kinetizma i arhiskulptoralnosti na polju razvoja savremene interaktivne kinetičke arhitekture. 